\title{
Blood lead in pregnant women in the urban slums of Lucknow, India
}

\author{
Shally Awasthi, Rajiv Awasthi, Vinod Kumar Pande, R C Srivastav, Howard Frumkin
}

\begin{abstract}
Objective-To determine the concentrations of blood lead (PbB) in pregnant women in the slums of Lucknow, north India.

Methods-Of the 203 designated municipal slums in Lucknow, 70 were randomly selected for study and a cohort of $\mathbf{5 0 0}$ pregnant women was enrolled. Each participant was interviewed with questions on possible sources of exposure to lead, surrogates of nutritional status were measured, and $\mathrm{PbB}$ was measured.
\end{abstract}

Results-The mean PbB was $14 \cdot 3 \mu \mathrm{g} / \mathrm{d} 1$ and $19 \cdot 2 \%$ of women had $\mathrm{PbB} \geqslant 20 \mu \mathrm{g} / \mathrm{dl}$. PbB was not associated with age, height, weight, gestation, or history of abortions, although higher PbB was associated with higher parity. Women living in inner city neighbourhoods near heavy vehicular traffic had PbB $2 \cdot 2 \mu \mathrm{g} / \mathrm{dl}$ higher (95\% confidence interval (95\% CI) 0.8 to 3.6$)$ than those living in other neighbourhoods. The $\mathrm{PbB}$ was not associated with reported use of piped water or the presence of paint in homes, and increasing PbB was unexpectedly associated with decreasing use of the eye cosmetic "surma" and the duration of gestation.

Conclusions-The high PbB found in this population raises concern about fetal development and points to the urgent need to reduce exposure to lead.

(Occup Environ Med 1996;53:836-840)

Keywords: lead; pregnancy; fetus; neurotoxicity; India

Although lead toxicity in children and adults is well recognised, exposure to lead is of special concern during pregnancy. Lead absorbed by the pregnant mother is readily transferred to the developing fetus..$^{1-3}$ There is evidence from animal studies that intrauterine exposure to lead may disrupt endocrine balance during pregnancy ${ }^{4}$ and lead to abnormalities of renal structure and function, ${ }^{6-8}$ abnormalities of the reproductive system, ${ }^{910}$ and neurodevelopmental toxicity ${ }^{11-13}$ in offspring. Human evidence corroborates these findings, linking prenatal exposure to lead with reduced birth weight and preterm delivery ${ }^{14} 15$ and with neurodevelopmental abnormalities in offspring. ${ }^{16-21}$ These concerns are especially salient for women and children in developing nations. Not only is exposure to lead common, but the toxicity of lead for pregnant women and their offspring may be amplified by nutritional deficiency 2223 and concomitant toxic exposures $^{24}$ which often occur in poor nations.

The aim of this study was to find the distribution of $\mathrm{PbB}$ among pregnant women in Lucknow, India, a densely populated city of two million in Uttar Pradesh, northern India. The study was prompted by the fact that leaded petrol is still used in Lucknow. Also, we were aware that a traditional Indian eye cosmetic "surma" contains lead, and might pose a hazard for women who use it through exposure to lead. This study was part of a larger ongoing study of the effect of maternal exposure to lead on neonatal birth weight and other outcomes of pregnancy.

\section{Methods}

This was a cross sectional study conducted in the urban slums of Lucknow. Under the national healthcare system, "slum" is an administrative designation that, in urban areas, means a population of about 1000 people, with incomes below the national poverty level and suboptimal living conditions. India's integrated child development scheme provides primary care for children and pregnant women in each slum through an "aganwadi" centre. Pregnant women in each slum register at their local centre to receive prenatal care, and are therefore listed. Of Lucknow's 203 slums, 70 were randomly selected and visited by a research assistant at least twice (in the same order) from June 1994 to July 1995. Pregnant women were identified by research assistants from the slum health workers' registers, and were invited to participate in the study. This process continued until 500 subjects were enrolled. Potential subjects were excluded if they declined to participate or if they indicated a likelihood of moving out of the slum in the next six months.

Personal interviews were conducted to collect data on age, reproductive history, and date of last menstrual period, correct to the nearest week. Participants were also asked about other sources of potential exposure to lead, including the source of drinking water, use of surma, and the presence of lead paint at home. Maternal nutritional status was estimated by measuring weight $(\mathrm{kg})$, height $(\mathrm{cm})$, and haemoglobin $(\mathrm{g} / \mathrm{dl})$. For measurement of $\mathrm{PbB}, 5 \mathrm{ml}$ of venous blood was taken after carefully cleaning the skin at the venepuncture site. Analysis of blood lead was performed at the laboratory of the Industrial Toxicology 
Concentrations of $\mathrm{PbB}$ among pregnant women in Lucknow.

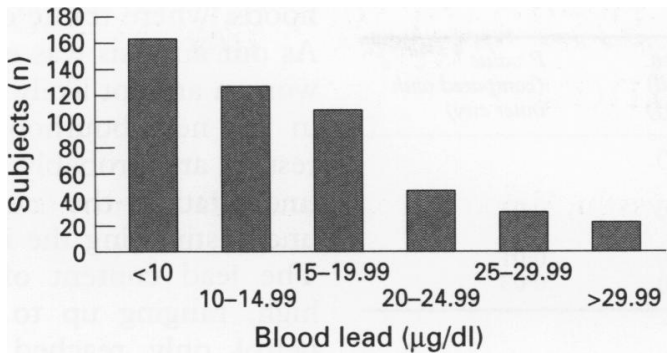

Research Centre (ITRC) in Lucknow, India. Five $\mathrm{ml}$ blood was digested in $\mathrm{HNO}_{3}: \mathrm{HClO}_{4}$ (6:1) for 24 hours and slowly evaporated to dryness. The process was repeated three times. The analyte was then brought to a volume of $4 \mathrm{ml}$ in $1 \% \mathrm{HNO}_{3}$. Blood lead was analysed with graphite furnace atomic absorbtion spectroscopy (GF-AAS; SpectrAA-250 Plus, Varian, Palo Alto, California). To account for any matrix effects present, measurement was effected through the use of a four point standard addition calibration with concentrations developed from a traceable standard (National Physical Laboratory, CSIR, New Delhi). The mean of four replicate analyses were used to assess the concentration. The coefficient of variation of the four analyses was $<2 \%$ for all samples. The ITRC laboratory participates in Indian national quality control programmes, and has applied for ISO 9000 certification.

This study was approved by the ethics committee of King George's Medical College, and all subjects gave informed consent before their participation.

After the sampling was completed, we hypothesised that certain neighbourhood characteristics might be associated with variations in the concentration of $\mathrm{PbB}$. We therefore divided the 70 slums into four categories, according to potential sources of environmental exposure to lead. These were (a) the inner city (with high population density and heavy stop and go vehicular traffic), (b) near industrial sources (factories producing batteries and paint, with medium population density and light vehicular traffic) that could potentially emit lead, $(c)$ near an industry unlikely to emit lead (a large beer distillery, with medium population density and light vehicular traffic), and (d) near roads (with low population density and heavy, fast moving vehicular traffic). Univariate analyses were conducted to characterise the distribution of $\mathrm{PbB}$ by demographic, clinical, and exposure related variables.

\section{Results}

From the 70 participating slums, 500 pregnant women were enrolled, an average of $7 \cdot 2$ women per slum. The mean $\mathrm{PbB}$ was 14.3 (SD 7.9$) \mu \mathrm{g} / \mathrm{dl}$, and the median $\mathrm{PbB}$ was 12.9 $\mu \mathrm{g} / \mathrm{dl}$. One hundred and eighty one women $(36.2 \%)$ had concentrations of $\mathrm{PbB}$ $\leqslant 10 \mu \mathrm{g} / \mathrm{dl}, 223(44.6 \%)$ had concentrations 11 to $20 \mu \mathrm{g} / \mathrm{dl}$, and $96(19 \cdot 2 \%)$ had concentrations $>20 \mu \mathrm{g} / \mathrm{dl}$, of whom 25 women had concentrations of $\geqslant 30 \mu \mathrm{g} / \mathrm{dl}$. The figure shows the distribution of $\mathrm{PbB}$. Table 1 shows the concentration of $\mathrm{PbB}$ against the distribution of various demographic, clinical, and exposure related variables. The concentrations of $\mathrm{PbB}$ did not vary with age, weight, height, haemoglobin, gestation, or reproductive history, except that more of the women with high concentrations of lead were multiparous.

Of the 70 participating slums, $36(51 \cdot 4 \%)$ were inner city slums, nine $(11.5 \%)$ were near industries that could potentially emit lead, five $(6.4 \%)$ were near an industry that did not emit lead, and $20(28.6 \%)$ were near highways. Table 2 shows the $\mathrm{PbB}$ results from these four categories of neighbourhood. Women in the inner city slums had a mean $\mathrm{PbB}$ that was $2 \cdot 2$ ( $95 \%$ confidence interval $(95 \% \mathrm{CI}) 0.8$ to $3 \cdot 6)$ $\mu \mathrm{g} / \mathrm{dl}$ higher than the combined concentration of women in the other categories.

As for other potential sources of exposure to lead, 193 subjects $(38.6 \%)$ reported the use of surma, 376 subjects $(75 \cdot 2 \%)$ reported the use

Table 1 Distribution of demographic, clinical, and exposure related variables by concentration of blood lead

\begin{tabular}{|c|c|c|c|c|c|}
\hline & \multicolumn{4}{|l|}{$P b B(\mu g / d l)$} & \multirow{2}{*}{$\begin{array}{l}P \text { value of } \\
\text { ANOVA }\end{array}$} \\
\hline & $\leqslant 10$ & $11-20$ & $>20$ & Total & \\
\hline $\begin{array}{l}\text { Number (\%) } \\
\text { Age (y, mean (SD)) } \\
\text { Weight (kg, mean (SD)) } \\
\text { Height (cm, mean (SD)) } \\
\text { Gestation (weeks, mean (SD)) } \\
\text { Parity (n (\%)): }\end{array}$ & $\begin{array}{r}181(36 \cdot 2) \\
26 \cdot 4(4 \cdot 8) \\
42 \cdot 9(6 \cdot 2) \\
149 \cdot 8(4 \cdot 7) \\
20 \cdot 2(6 \cdot 6)\end{array}$ & $\begin{array}{r}223(44 \cdot 6) \\
26 \cdot 3(4 \cdot 6) \\
42 \cdot 5(6 \cdot 5) \\
149 \cdot 9(4 \cdot 9) \\
19 \cdot 9(6 \cdot 6)\end{array}$ & $\begin{array}{c}96(19 \cdot 2) \\
26 \cdot 9(4 \cdot 8) \\
43 \cdot 1(6 \cdot 8) \\
150 \cdot 1(4 \cdot 8) \\
19 \cdot 5(6 \cdot 6)\end{array}$ & $\begin{array}{l}500 \\
26 \cdot 5(4 \cdot 7) \\
42 \cdot 79(6 \cdot 45) \\
149 \cdot 9(4 \cdot 8) \\
19 \cdot 9(6 \cdot 6)\end{array}$ & $\begin{array}{l}\text { NS } \\
\text { NS } \\
\text { NS } \\
\text { NS }\end{array}$ \\
\hline & $\begin{array}{r}37(20 \cdot 4) \\
144(79 \cdot 6)\end{array}$ & $\begin{array}{r}47(19 \cdot 7) \\
176(78 \cdot 9)\end{array}$ & $\begin{array}{r}6(6 \cdot 25) \\
90(93 \cdot 7)\end{array}$ & $\begin{array}{r}90(18 \cdot 0) \\
410(82 \cdot 0)\end{array}$ & \\
\hline $\begin{array}{l}\text { Abortions (n (\%)): } \\
\quad 0 \\
\quad \geqslant 1\end{array}$ & $\begin{array}{r}156(86 \cdot 2) \\
25(13 \cdot 8)\end{array}$ & $\begin{array}{r}193(86 \cdot 5) \\
30(13 \cdot 5)\end{array}$ & $\begin{array}{l}84(87 \cdot 5) \\
12(12 \cdot 5)\end{array}$ & $\begin{array}{r}433(86 \cdot 6) \\
67(13 \cdot 4)\end{array}$ & 0.77 \\
\hline $\begin{array}{l}\text { Trimester (n (\%)): } \\
\quad 1 \\
2 \\
3\end{array}$ & $\begin{array}{l}14(7 \cdot 7) \\
111(61 \cdot 3) \\
56(30 \cdot 9)\end{array}$ & $\begin{array}{c}17(7 \cdot 6) \\
136(60 \cdot 9) \\
70(31 \cdot 4)\end{array}$ & $\begin{array}{c}9(9 \cdot 4) \\
58(60 \cdot 4) \\
29(30 \cdot 2)\end{array}$ & $\begin{array}{r}40 \\
305 \\
155\end{array}$ & 0.93 \\
\hline $\begin{array}{l}\text { Residence }(\mathrm{n}(\%))^{\star} \text { : } \\
\quad 1 \\
2 \\
3 \\
4 \\
4 \\
\text { Lead paint }(\mathrm{n}(\%)) \\
\text { Piped water (n (\%)) } \\
\text { Surma (n (\%)) }\end{array}$ & $\begin{array}{r}61(33 \cdot 7) \\
29(16 \cdot 0) \\
29(16 \cdot 0) \\
62(34 \cdot 3) \\
58(32 \cdot 0) \\
131(72 \cdot 4) \\
78(43 \cdot 1)\end{array}$ & $\begin{array}{r}86(38 \cdot 6) \\
53(23 \cdot 8) \\
24(10 \cdot 8) \\
60(26 \cdot 9) \\
47(21 \cdot 1) \\
172(77 \cdot 1) \\
89(39 \cdot 9)\end{array}$ & $\begin{array}{l}50(52 \cdot 1) \\
12(12 \cdot 5) \\
11(11 \cdot 5) \\
23(23 \cdot 9) \\
23(23 \cdot 9) \\
73(76 \cdot 0) \\
26(27 \cdot 1)\end{array}$ & $\begin{array}{r}197 \\
94 \\
64 \\
145 \\
128 \\
376 \\
193\end{array}$ & $\begin{array}{l}0.0045 \\
0.06 \\
0.39 \\
0.015\end{array}$ \\
\hline
\end{tabular}

$\star_{1}=$ Inner city (with heavy vehicular traffic); 2 = industrial (with potential lead emissions); $3=$ industrial (without potential lead emissions); 4 = near highway. 
Table 2 Distribution of $\mathrm{PbB}$ by type of neighbourhood

\begin{tabular}{|c|c|c|c|c|}
\hline Type of neighbourhood & $\begin{array}{l}\text { Slums } \\
n\end{array}$ & $\begin{array}{l}\text { Women } \\
n\end{array}$ & $\begin{array}{l}\text { Concentration } \\
\text { of } P B B(\mu g / d l) \\
\text { (means (SD)) }\end{array}$ & $\begin{array}{l}\text { Pvalue } \\
\text { (compared with } \\
\text { inner city) }\end{array}$ \\
\hline $\begin{array}{l}\text { Inner city } \\
\text { Industrial (with potential }\end{array}$ & 36 & 197 & $15 \cdot 65(8 \cdot 17)$ & \\
\hline $\begin{array}{l}\mathrm{Pb} \text { emissions) } \\
\text { Industrial (without potential }\end{array}$ & 9 & 94 & $13 \cdot 57(6.40)$ & 0.03 \\
\hline $\begin{array}{l}\text { Pb emissions) } \\
\text { Near highway }\end{array}$ & $\begin{array}{r}5 \\
20\end{array}$ & $\begin{array}{r}64 \\
145\end{array}$ & $\begin{array}{l}12 \cdot 99(7 \cdot 14) \\
13 \cdot 64(8 \cdot 40)\end{array}$ & $\begin{array}{l}0.01 \\
0.03\end{array}$ \\
\hline
\end{tabular}

of piped water, and $128(25 \cdot 6 \%)$ reported the presence of paint on surfaces in their homes. The reported use of surma decreased with increasing $\mathrm{PbB}$, and the reported presence of lead paint showed a trend in the same direction; both findings were unexpected.

\section{Discussion}

This study showed increased concentrations of $\mathrm{PbB}$ among pregnant women in the slums of Lucknow. In a sample of 500 women, the mean $\mathrm{PbB}$ was $14.3 \mu \mathrm{g} / \mathrm{dl}$. Ninety six women (19.2\%) had $\mathrm{PbB}>20 \mu \mathrm{g} / \mathrm{dl}$, of whom 25 had $\mathrm{PbB} \geqslant 30 \mu \mathrm{g} / \mathrm{dl}$.

These results confirm previous data showing high concentrations of lead in the Indian population. In the early $1980 \mathrm{~s}$, mean (SD) concentrations of $\mathrm{PbB}$ among female teachers in various Indian cities were as follows: Ahmedabad 14.7 (7.26), Bangalore $19 \cdot 8$ $(10 \cdot 15)$, and Calcutta $10.8(3.46) \mu \mathrm{g} / \mathrm{dl}^{25} \mathrm{At}$ the same time, a population study in Bombay found a mean concentration of $\mathrm{PbB}$ to be 35.6 $\mu \mathrm{g} / \mathrm{dl}^{26}$ Another recent study of pregnant women in Lucknow found a mean (SD) $\mathrm{PbB}$ of $19.4(8.51) \mu \mathrm{g} / \mathrm{dl}$ among those with normal deliveries and $22.52(8 \cdot 76) \mu \mathrm{g} / \mathrm{dl}$ among those with various adverse outcomes such as preterm delivery, stillbirth, and spontaneous abortion. ${ }^{27}$ The higher concentrations found in the previous study in Lucknow may be explained by the fact that it was based in hospital, and involved a population selected for high obstetric risk.

These results suggest that Indian women of child bearing age have a higher biological lead burden than their counterparts in other developing countries. Table 3 shows that mean concentrations of $\mathrm{PbB}$ in pregnant women in developing nations ranged between 5.5 and $15.2 \mu \mathrm{g} / \mathrm{dl}$, with the exception of a small study in Durban, South Africa with higher concentrations. There are several reasons why Indian women might have higher concentrations of $\mathrm{PbB}$. The leading source implicated by our data was motor vehicle traffic as $\mathrm{PbB}$ was higher among women in inner city neighbour-

Table 3 Previously reported $\mathrm{PbB}$ among pregnant women in developing nations

\begin{tabular}{llcl}
\hline Location & Subjects & $P b B(\mu g / d l)($ mean $(S D))$ & Reference (year) \\
\hline Riyadh & 124 & $5 \cdot 5(2 \cdot 6)$ & $28(1995)$ \\
Bangkok & 500 & $6 \cdot 2(2 \cdot 0)$ & $29(1994)$ \\
Mexico City: & 250 & $9 \cdot 0(6 \cdot 0)$ & $30(1993)$ \\
$\quad$ 12 weeks & 250 & $8 \cdot 5(6 \cdot 2)$ & $30(1993)$ \\
$\quad$ At term & 21 & $21 \cdot 7(2 \cdot 9)$ & $31(1993)$ \\
Durban & 165 & $14 \cdot 1(6 \cdot 8)$ & $32(1990)$ \\
Shanghai & 147 & $6 \cdot 5(0 \cdot 2)$ & $33(1991)$ \\
Taiwan & 114 & $15 \cdot 2(4 \cdot 2)$ & $34(1985)$ \\
Kuala Lumpur & &
\end{tabular}

hoods, where traffic exposure is most intense. As our analysis was ecological, and individual women are not likely to spend all of their time in the neighbourhoods where they live, our results are probably biased toward the null, understating the neighborhood effect, and underestimating the impact of lead in petrol. The lead content of Indian petrol remains high, ranging up to $0.56 \mathrm{~g} / 1$, and unleaded petrol only reached the Indian market in $1995 .{ }^{35}$ Leaded petrol is well established as an important factor in concentrations of lead in the population.

Several other environmental sources of lead may affect Indian women, including surma, contaminated water supplies, and lead paints. However, our results did not point to any of these sources, and if anything the results for lead paint and surma showed an unexpected trend away from an association. Before concluding that these sources are harmless in India, further consideration is necessary.

Surma and a related but more finely ground cosmetic kohl have been found to contain lead at concentrations as high as $92 \%,{ }^{36-39}$ although specific data on surma from Lucknow are not available. Studies of children in Israel, ${ }^{39}$ Saudi Arabia, ${ }^{4041}$ Kuwait, ${ }^{37}$ the United Kingdom, ${ }^{42-44}$ and the United States ${ }^{45}$ have linked the use of these cosmetics with increased $\mathrm{PbB}$, although studies of children in Delhi ${ }^{46}$ and Glasgow ${ }^{47}$ did not find such an association. The presumed routes of absorption in children are conjunctival (the cosmetics are applied directly to the palpebral conjunctiva) and gastrointestinal (when children rub their eyes and lick their fingers). There is also evidence that adults who use surma may develop increased $\mathrm{PbB}$, based on a study of pregnant women in Saudi Arabia. ${ }^{48}$ The negative findings for surma in our study may be explained in several ways: the lead content of local surma may be negligibly low, the impecunious subjects in this study may use surma sparingly or infrequently due to its cost, there may have been exposure misclassification due to misreporting of use of surma, or absorption of lead from local surma may be low. More detailed study of surma in India would help clarify the risk from this common cosmetic.

The negative findings for water supplies may be due to exposure misclassification by subjects unaware of their household water source. It may also indicate low consumption of tap water, or low concentrations of lead in tap water due to limited lead in Lucknow's water distribution system or water that does not disolve lead due to hardness or alkalinity. Finally, the negative findings for paint are perhaps least surprising. Most homes in Lucknow slums, if they have any painted surfaces at all, only have paint on limited areas such as door frames. Moreover, as leaded paint is more expensive than alternatives, much of the paint used in homes is probably lead free. Therefore, the high prevalence of reported lead paint $(25.6 \%)$ probably reflects misclassification.

The toxicokinetics of lead in pregnancy are complex. ${ }^{49}$ Previous reports have noted a fall 
in $\mathrm{PbB}$ during the second trimester of pregnancy, ${ }^{50}$ attributed to haemodilution caused by the expansion of blood volume. ${ }^{51}$ Others $^{52}$ have found an increase in $\mathrm{PbB}$ during pregnancy, possibly due to the release of lead from bone stores. ${ }^{49}$ In our population, the $\mathrm{PbB}$ did not vary with the trimester of pregnancy. This may reflect the unusually high concentrations of $\mathrm{PbB}$, or it may be related to deficiencies of iron, calcium, or zinc, which facilitate intestinal absorption of lead ${ }^{52}$ and mobilisation of bone lead during pregnancy. ${ }^{49} 53$ The effect of pregnancy on lead toxicokinetics needs further investigation.

A weakness of this study is that we did not attempt to ascertain exposures to other potential sources of lead. The most important of these are direct or secondary occupational exposures. Consumer goods with paint containing lead, contaminated food, and contaminated beverages are other potential sources. Future studies should attempt to ascertain the importance of these exposures.

The blood lead concentrations in the women in this study were increased to an alarming extent. In combination with poor nutrition, infectious diseases, and other disadvantages associated with poverty, the exposure to lead threatens the normal development of children. Aggressive approaches to primary prevention are needed, including the removal of lead from petrol, an intervention known to decrease concentrations of lead in the population. ${ }^{54}$ Further research is necessary to identify other sources of exposure to lead, such as in consumer products and cosmetics, and to eliminate these as well.

This work was supported by a grant from the Environmental and Occupational Health Initiative of the International Clinical Epidemiology Network (INCLEN), from the Rockefeller Foundation.

1 Buchet JP, Roels H, Hubermont G, Lauwerys R. Placental transfer of lead, mercury, cadmium, and carbon monoxide in women. II. Influence of some epidemiological factors on the frequency distributions of the biological indices in maternal and umbilical cord blood. Environ Res 1978;15: 494-503.

2 Roels H, Hubermont G, Buchet JP, Lauwerys R. Placental transfer of lead, mercury, cadmium, and carbon monoxide in women. III. Factors influencing the accumulation of heavy metals in the placenta and the relationship between metal concentration in the placenta and in maternal and cord blood. Environ Res 1978;16:236-47.

3 Ong CN, Phoon WO, Law HY, Tye CY, Lim HH. Concentrations of lead in maternal blood, cord blood, Concentrations of lead in maternal blood, cord
and breast milk. Arch Dis Child 1985;60:756-9.

4 Foster WG. Reproductive toxicity of chronic lead exposure in the female cynomolgus monkey. Reprod Toxicol 1992; 6:123-31.

5 Sierra EM, Tiffany-Castiglioni E. Effects of low-level lead exposure on hypothalamic hormones and serum progesterone levels in pregnant guinea pigs. Toxicology 1992;72: 89-97.

6 Vyskocil A, Cizkova M, Tejnorova I. Effect of prenatal and postnatal exposure to lead on kidney function in male and female rats. $₹$ Appl Toxicol 1995;15:327-8.

7 Oberley TD, Friedman AL, Moser R, Siegel FL. Effects of lead administration on developing rat kidney. II. Functional, morphologic, and immunohistocher studies. Toxicol Appl Pharmacol 1995;131:94-107.

8 Moser R, Oberley TD, Daggett DA, Friedman AL, Johnson JA, Siegel FL. Effects of lead administration on developing rat kidney. I. Glutathione S-transferase isoenzymes. Toxicol Appl Pharmacol 1995;131:85-93.

9 Coffigny H, Thoreux-Manlay A, Pinon-Lataillade G, Monchaux G, Masse R, Soufir JC. Effects of lead poisoning of rats during pregnancy on the reproductive system and fertility of their offspring. Hum Exp Toxicol 1994;13: $241-6$

10 Corpas I, Gaspar I, Martinez S, Codesal J, Candelas S, Antonio MT. Testicular alterations in rats due to gesta- tional and early lactational administration of lead. Reprod Toxicol 1995;9:307-13.

11 Legare ME, Castiglioni AJ Jr, Rowles TK, Calvin JA, Snyder-Armstead C, Tiffany-Castiglioni E. Morphological alterations of neurons and astrocytes in guinea pigs exposed to low levels of inorganic lead. Neurotoxicology 1993;14:77-80.

12 Buchheim K, Noack S, Stoltenburg G, Lilienthal H, Winneke G. Developmental delay of astrocytes in hippocampus of rhesus monkeys reflects the effect of preand postnatal chronic low level lead exposure. Neurotoxicol 1994;15:665-9.

13 Tang HW, Liang YX, Hu XH. Effects of low level lead exposure on behavior of young rats. Chung Kuo Yao Li Hsueh Pao 1994;15:316-9.

14 Tabacova S, Balabaeva L. Environmental pollutants in relation to complications of pregnancy. Environ Health Perspect 1993;101(suppl 2):27-31

15 Andrews KW, Savitz DA, Hertz-Picciotto I. Prenatal lead exposure in relation to gestational age and birth weight: a review of epidemiologic studies. Am f Ind Med 1994;26: 13-32.

16 Bellinger D, Leviton A, Waternaux C, Needleman $H$, Rabinowitz $M$. Longitudinal analysis of prenatal and postnatal lead exposure and early cognitive development. N Engl f Med 1987;316:1037-43.

17 Dietrich $\mathrm{K}$, Krafft KM, Bornschein RI, Hammond PB, Berger O, Succop PA, Bier M. Low level fetal lead exposure effects on neurobehavioral development in early sure effects on neurobehavioral
infancy. Pediatrics 1987;80:721-30.

18 Huel G, Tubert P, Frery N, Moreau T, Dreyfus J. Joint effect of gestational age and maternal lead exposure on psychomotor development of the child at six years. Neurotoxicology 1992;13:249-54.

19 Leviton A, Bellinger D, Allred EN, Rabinowitz M, Needleman H, Schoenbaum S. Pre- and postnatal lowlevel lead exposure and children's dysfunction in school. Environ Res 1993;60:30-43.

20 Bellinger D, Leviton A, Allred E, Rabinowitz M. Pre- and postnatal lead exposure and behavior problems in schoolaged children. Environ Res 1994;66:12-30.

21 Rothenberg SJ, Poblano A, Garza-Morales S. Prenatal and perinatal low level lead exposure alters brainstem auditory evoked responses in infants. Neurotoxicology 1994; 15:695-9.

22 West WL, Knight EM, Edwards $\mathrm{CH}$, Manning $\mathrm{M}$, Spurlock B, James H, et al. Maternal low level lead and pregnancy outcomes. ₹ Nutr 1994;124(suppl 6):981S-6S.

23 Bogden JD, Kemp FW, Han S, Murphy M, Fraiman M, Czerniach D. Dietary calcium and lead interact to modify maternal blood pressure, erythropoiesis, and fetal and neonatal growth in rats during pregnancy and lactation. $\mathcal{F}$ Nutr 1995;125:990-1002.

24 Kristensen P, Eilertsen E, Einarsdottir E, Haugen A, Skaug V, Ovrebo S. Fertility in mice after prenatal exposure to benzo[a]pyrene and inorganic lead. Environ Health Perspect 1995;103:588-90.

25 Parikh DJ. Human exposure to lead: an overview in India. Indian foumal of Industrial Medicine 1990;36:63-75

26 Annapurna V, Mahajan BA, Murti MV. Studies of blood lead levels in Bombay's citizens. Indian fournal of Environmental Studies 1985;24:239-43.

27 Saxena DK, Singh C, Murthy RC, Mathur N, Chandra SV. Blood and placental lead levels in an Indian city: a preliminary report. Arch Environ Health 1994;49:106-10.

28 Al-Saleh I, Khalil MA, Taylor A. Lead, erythrocyte protoporphyrin, and hematological parameters in normal maternal and umbilical cord blood from subjects of maternal and umbilical cord blood from subjects of 50:66-73.

29 Phuapradit W, Jetsawangsri T, Chaturachinda K, Noinongyao N. Maternal and umbilical cord blood lead levels in Ramathibodi Hospital, 1993. 7 Med Assoc Thai 1994;77:368-72.

30 Fuentes-Aguilar L, Soto-Mora C. Influence of lead on pregnant women in metropolitan Mexico City. Bull Environ Contam Toxicol 1993;50:533-9.

31 Chetty N, Jinabhai CC, Green-Thompson RW. Lead levels in maternal and umbilical cord blood at King Edward in maternal and umbilical cord blood at King Edwar

32 Li PJ, Sheng YZ, Wang QY, Gu LY. Transfer of lead via placenta and milk in humans. Industrial Health and Occupational Disease 1990;16:207-10.

33 Soong Y-K, Tseng R, Liu C, Lin P-W. Lead, cadmium, arsenic, and mercury levels in maternal and fetal cord blood. $f$ Formos Med Assoc 1991;90:59-65.

34 Aslam M, Davis SS, Healy MA. Heavy metals in some Asian medicines and cosmetics. Public Health 1979;93: 274-84.

35 Thomas V, Spiro G. Emissions and exposure to metals: cadmium and lead. In: Socolow RW, ed. Industrial ecology and global change. New York: Cambridge University and global

36 Aslam M, Healy MA, Davis SS, Ali AR. Surma and blood lead in children. Lancet 1980;i:658-9.

37 Fernando NP, Healy MA, Aslam M, Davis SS, Hussein A Lead poisoning and traditional practices: the consequences for world health. A study in Kuwait. Public Health 1981;95:250-60.

38 Parry C, Eaton J. Kohl: a lead-hazardous eye makeup from the third world to the first world. Environ Health Perspect 1991;94:121-3.

39 Nir A, Tamir A, Zelnik N, Iancu TC. Is eye cosmetic a source of lead poisoning? Isr ₹ Med Sci 1992;28:417-21. 
40 Abdullah MA. Lead poisoning among children in Saudi Arabia. Yournal of Tropical Medical Hygiene 1984;87:

41 Alkhawajah AM. Alkohl use in Saudi Arabia. Extent of use and possible lead toxicity. Trop Geogr Med 1992;44:373-7.

42 Warley MA, Blackledge P, O'Gorman P. Lead poisoning from eye cosmetic. BMF 1968;i:117.

43 Snodgrass GJAI, Ziderman DA, Gulati V, Richards J. Cosmetic plumbism. BMF 1973;4:230

44 Ali AR, Smales ORC, Aslam M. Surma and lead poisoning. $B M \Im$ 1978;ii:915-6.

45 Sprinkle RV. Leaded eye cosmetics: a cultural cause of elevated lead levels in children. If Fam Pract 1995;40: v58-62.

46 Gogte ST, Basu N, Sinclair S, Ghai OP, Bhinde NK. Blood lead levels of children with pica and surma use. Indian $\mathcal{Y}$ Pediatr 1991;58:513-9.

47 Attenburrow AA, Campbell S, Logan RW, Goel KM. Surma and blood lead levels in Asian children in Glasgow. Lancet 1980;i:323.

48 Moghraby SA, Abdullah MA, Karrar O, Akiel AS, Shawaf
TA, Majid YA. Lead concentrations in maternal and cord blood in women users of surma eye cosmetics. Ann Trop Paediatr 1989;9:49-53.

49 Silbergeld EK. Lead in bone: implications for toxicology during pregnancy and lactation. Environ Health Perspect 1991;91:63-70.

50 Rothenberg SJ, Karchmer S, Schnaas L, Perroni E, Zea F, Alba JF. Changes in serial blood levels during pregnancy. Environ Health Perspect 1994;102:876-80.

51 Mahaffey KR. Biokinetics of lead during pregnancy. Fundam Appl Toxicol 1991;16:15-6.

52 Jacobssen IB, Soderberg HA, Nordberg GF, Ekesrydh S, Englyst V. Biological monitoring of arsenic, lead and cadmium in occupationally and environmentally exposed mium in occupationally and environmentally exposed pregn $50-3$.

53 Fullmer CS. Intestinal interaction of lead and calcium. Neurotoxicol 1992;13:799-808.

54 Pirkle JL, Brody DJ, Gunter EW, Kramer RA, Paschal DC, Flegal KM, Matte TD. The decline in blood lead levels in the United States. $\mathscr{F} A M A$ 1994;272:284-91.

\section{Rejected manuscripts}

From February 1994, authors whose submitted articles are rejected will be advised of the decision and one copy of the article, together with any reviewers' comments, will be returned to them. The fournal will destroy remaining copies of the article but correspondence and reviewers' comments will be kept. 